\title{
Exploring past human impacts over time and space
}

\author{
Émilie Saulnier-Talbot' ${ }^{1}$ N. Dubois ${ }^{2}$ and J. Boyle ${ }^{3}$
}

The recently launched Human Traces working group (pastglobalchanges.org/humantraces) aims to bring together scientists from various fields whose work examines archives of anthropogenic activity in the environment. The main goal of the working group is to assemble a shared community resource of Holocene stratigraphic archives optimized to assess drivers and responses to human impacts on the environment and to identify periods of stability and change leading up to the Anthropocene epoch.

In 2019, the Subcommission on Quaternary Stratigraphy voted that the Anthropocene should be treated as a formal chronostratigraphic unit defined by a Global Boundary Stratotype Section and Point (GSSP), to be placed within the 20th century. This vote ended the "Anthropocene" debate, but left the long legacy of pre-Anthropocene human impacts unchanged. Although defining a global "golden spike" has chronostratigraphic value, it may lead to the assumption that all major environmental impacts by human activities are recent. A mid-20th century start to the Anthropocene does not represent the varied history of human activity with regionally asynchronous impacts on the environment that manifested dissimilarly in different parts of the world. Substantial preAnthropocene impacts, which can be traced back several thousands of years, and a quantitative understanding of them is essential to managing the planet's resources with the goal of moving towards sustainability.

Lake sediments and other stratigraphic archives such as ice cores serve as long-term records of natural variability and humaninduced changes (Fig. 1), making it possible to assess environmental responses to change on various timescales and to link them with either climatic or anthropogenic drivers (Mills et al. 2017). They also allow us to define targets and reference conditions for ecosystem management and conservation, providing a longer-term perspective for recent global changes in the context of the Anthropocene. However, there is still a paucity of long-term environmental regional data, and a global synthesis of human impacts recorded in stratigraphic archives is also lacking.

\section{Scientific goals and activities}

Human Traces will focus its scientific activities on collecting and analyzing evidence of the long legacy and build-up of pre-Anthropocene human impacts on the environment with the overarching goal of addressing knowledge gaps about spatial and temporal variations in early human impacts (Dubois et al. 2018). Integral to this work will be the creation of a suitable database of long-term evidence of human impacts from the paleorecord, developed following wide consultation with interested parties.

Activities of the working group will include regular online meetings (every three months) in order to ensure the progress of activities and exchange of information in preparation for in-person workshops. These yearly, if possible, workshops will allow for online participation as well. Meetings and workshops will focus on the identification of the most desirable data types, the collection and quality control of data, database creation, as well as working on crafting of manuscripts based on specific questions relating to various pre-Anthropocene environmental impacts around the world. Summer schools will also be held to foster networking for graduate students, postdocs, and earlycareer scientists interested in investigating anthropogenic environmental impacts in natural archives at various spatial and temporal scales.

\section{Upcoming meetings and workshops} Our first meeting will be held online in May 2021 (pastglobalchanges.org/ calendar/2021/127-pages/2118). An ongoing survey regarding population of the database will be developed and sent out to the
PAGES community. The second meeting, focused on the theme: "What is a human impact/trace in a record of broad interest?" and planned for September 2021 (pastglobalchanges.org/calendar/2021/127pages/2123), will initiate exchanges with other PAGES working groups that also focus on human dimensions: LandCover6k (pastglobalchanges.org/landcover6k), Paleoclimate and the Peopling of the Earth (PEOPLE 3000; pastglobalchanges. org/people3000), and Integrating diverse knowledge systems for environmental policy (DiverseK; pastglobalchanges.org/diversek).

An in-person workshop, specific to lakeand coastal-sediment records, is planned in March 2022, in association with the International Paleolimnology Congress in Bariloche, Argentina, and an interdisciplinary workshop will be held in association with the PAGES Open Science Meeting in Agadir, Morocco, in May 2022. Visit our webpage for more information and to stay up to date: pastglobalchanges.org/science/wg/ human-traces/meetings

You can also follow the Human Traces working group on social media! Twitter: @HTraces

Facebook: facebook.com/HTraces

\section{AFFILIATIONS}

'Départements de biologie et de géographie, Université Laval, Québec, Canada 2Oberflächengewässer, SURF, EAWAG,

Kastanienbaum, Switzerland

${ }^{3}$ Department of Geography and Planning, University of Liverpool, UK

\section{CONTACT}

Nathalie Dubois: nathalie.dubois@eawag.ch

REFERENCES

Dubois N et al. (2018) Anthr Rev 5: 28-68

Mills K et al. (2017) WIREs Water 4: e1404

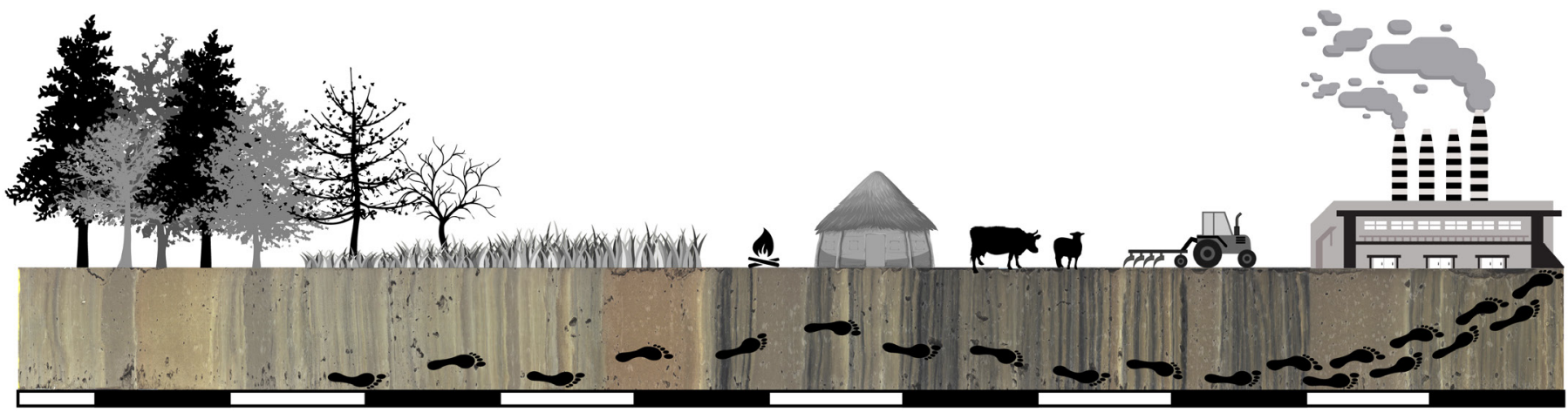

Figure 1: Human traces in sediment archives reflect the history of anthropogenic activities. 